\title{
Influence of Porcine Housing Density on Species Diversity and Number of Airborne Microorganisms at Fattening Facilities
}

\author{
Ž. PAVIČIĆ ${ }^{1}$, T. BALENOVIĆ ${ }^{2}$, H. VALPOTIĆ 3 , A. TOFANT ${ }^{1}$, M. POPOVIĆ $^{4}$, \\ M. BALENOVIĆ 5 , K. MATKOVIĆ ${ }^{1}$, I. VALPOTIĆ 4 , \\ ${ }^{1}$ Department of Animal Hygiene, Environment and Ethology, ${ }^{2}$ Department of Stockbreeding, ${ }^{3}$ Department of \\ Animal Nutrition, ${ }^{4}$ Department of Biology, Faculty of Veterinary Medicine, University of Zagreb, Zagreb, 5 \\ Croatian Veterinary Institute, Zagreb, Croatia \\ Received December 28, 2005 \\ Accepted June 30, 2006
}

\begin{abstract}
Pavičić Ž., T. Balenović, H. Valpotić, A. Tofant, M. Popović, M. Balenović, K. Matković, I. Valpotić: Influence of Porcine Housing Density on Species Diversity and Number of Airborne Microorganisms at Fattening Facilities. Acta Vet. Brno 2006, 75: 533-540.

Microbiological composition of air, as a factor of ambient conditions in animal facilities can significantly influence performance, health and animal welfare in the swine production. The aim of this investigation was to determine, by monitoring primary microclimatic conditions, the possible association of the number of fattening pigs per unit of housing space with species diversity and number of airborne microorganisms. The research was conducted at a fattening and finishing facility of $450 \mathrm{~m}^{2}$ (equipped with 44 pens designed for 10 animals each) with low-pressure ventilation in three different trials. The first trial was conducted during the autumn-winter period with the capacity of 440 animals $\left(0.7 \mathrm{~m}^{2}\right.$ of pen area per fattening pig), the second trial was conducted during the winter-spring period with 356 animals $\left(0.8 \mathrm{~m}^{2}\right.$ of pen area per fattening pig), and the third trial was conducted during the spring-summer period with 312 animals $\left(1.0 \mathrm{~m}^{2}\right.$ of pen area per fattening pig). The air samples for isolation of fungi and mesophilic, haemolytic, and coliform bacteria were taken and microclimatic conditions were monitored during each trial at the same consecutive weekly periods. According to the data obtained from all trials, the total number of bacteria and fungi did not exceed $10^{4}$ and $10^{3} \mathrm{CFU}$ per $\mathrm{m}^{3}$, respectively. The most numerous were gram-positive bacteria, followed by gram-negative bacteria and fungi. The total number of airborne microorganisms correlates significantly (at $p<0.05)$ with porcine housing density. These data may be useful for the assessment of housing density at fattening facilities that will not compromise swine health and welfare regarding the microbiological air quality, and thus may contribute to the implementation of optimal rearing conditions in large-scale animal producing units.
\end{abstract}

Fattening pigs, housing, airborne bacteria, fungi

Hygienic air quality is an important factor in modern pig farms because it represents one of the abiotic components necessary for the health and welfare of animals (Duchaine et al. 2000, Hadina et al. 2003). Namely, air in the facilities can serve as a reservoir for primary and potentially pathogenic microorganisms that are important in the etiology of infectious and allergic diseases (Wathes 1994). Therefore, one of the indicators of hygienic air quality is determining total microorganism numbers, which can be associated with dust particles, water droplets, or which can be in free floating condition. The transition of microorganisms to an aerogenic form occurs during breathing, coughing and sneezing of animals and workers at the farm, and through different activities such as food distribution or manure deposition, and during convection in the environment. Namely, because of the temperature difference, an exchange of material particles occurs between the warmer organism surface and the cooler surrounding air, resulting in the release of microorganisms from the animal body to the air. Besides, the process of microorganisms returning to the aerosol phase known as recontamination is very important (Müller 2000). Recently, many

Address for correspondence:

Doc. dr. sc. Maja Popovic

Department of Biology

Faculty of Veterinary Medicine, University of Zagreb

Heinzelova 55, 10000 Zagreb, Croatia

Phone: +38512390155

Fax: +38512441390

e-mail: mpopovic@vef.h

http://www.vfu.cz/acta-vet/actavet.htm 
studies have focused on air hygiene in the swine pens (Zucker et al. 2000; Zucker and Müller 2000; Zucker and Müller 2000a; Kluczek and Kluczek 2000; Zucker and Müller 2002) with different values of total air microorganism numbers, depending on the housing and climate characteristics of a certain area, and the ventilation system of the investigated facility. The highest interest for this type of study was towards the farrowing facilities because of the strict control of conditions with the least microorganisms expected and the fattening facilities in which the adult and more resistant animals with the greatest numbers of microorganisms are expected (Donham et al. 1986). Comparison of total microorganism numbers in different production phases is frequent (Attwood et al. 1987; Cormier et al. 1990; Chang et al. 2001), although the comparison of results in the same production phase, depending on the density of housed animals in the object, can also be equally interesting. This way it may be possible to determine how either high or low numbers of animals, during identical housing conditions, influence the incidence of species and numbers of microorganisms at swine fattening and finishing facilities.

\section{Experimental design}

\section{Materials and Methods}

The study was conducted in a closed swine fattening facility in three trials with different animal numbers per one unit of housing space. The fattening object was $30 \mathrm{~m}$ long, $15 \mathrm{~m}$ wide, and $5.5 \mathrm{~m}$ high. There are three hallways in the object, $27.5 \mathrm{~m}$ long, and $1.2 \mathrm{~m}$ wide, and two side hallways $15 \mathrm{~m}$ long, and $1.25 \mathrm{~m}$ wide. Each lateral side of the object had thirty windows, $0.85 \mathrm{~m}$ high, and $0.55 \mathrm{~m}$ wide, and there were seven ventilation shafts in the ceiling. Air exchange was based on artificial ventilation, when fresh air flowed in through windows with size regulation because of lower pressure in the compound, while the polluted air was sucked out through ventilation shafts on the ceiling. The pens are situated on a semi slated concrete floor placed into two double rows interconnected with a common rear railing. Each row consists of 11 pens (total of 44 pens) $2.85 \mathrm{~m}$ long, and $2.5 \mathrm{~m}$ wide. Animals were fed with an automatic feeder system (Big Dutchman) that minimized dusting in the object. In the first trial, 10 animals per pen were assigned with the total of 440 pigs $\left(0.7 \mathrm{~m}^{2}\right.$ of pen space per animal $)$, in the second trial 8 animals per pen with the total of 356 pigs $\left(0.9 \mathrm{~m}^{2}\right.$ of pen space per animal $)$, and in the third trial 7 animals per pen with the total of 312 pigs $\left(1.0 \mathrm{~m}^{2}\right.$ of pen space per animal). The duration of each trial was 110 days (the first trial from September $15^{\text {th }}$ to January $3^{\text {rd }}$, the second trial from January $8^{\text {th }}$ to April $28^{\text {th }}$ and the third trial from May $4^{\text {th }}$ to August 22 ${ }^{\text {nd }}$ ). The trials were conducted on Swedish Landrace piglets with the initial average weight of $25 \mathrm{~kg}$. The average daily weight gain during the fattening period was $700 \mathrm{~g}$, and the total weight gain was $75 \mathrm{~kg}$. Animals were fed mash containing $16 \%$ crude protein, $8 \%$ crude fat, $6 \%$ crude fiber and $12.5 \mathrm{MJ} / \mathrm{kg}$ of metabolic energy (ME) until $60 \mathrm{~kg}$ live weight, and mash containing 14\% crude protein, $10 \%$ crude fat, $7 \%$ crude fiber and $12.5 \mathrm{MJ} / \mathrm{kg}$ of metabolic energy (ME) until the end of fattening period.

\section{Air sampling}

Air samples were taken in the middle of each week of fattening during the resting period (between 13:00 and 14:00 h) and 15 air samples were collected in each trial. The air collector SAS $100^{\mathrm{TM}}$ (PBI International, Italy) was used for this purpose. Each petri dish, with the radius of $90 \mathrm{~mm}$, was filled with $15 \mathrm{ml}$ of culture medium specific for growing particular bacterial species to be identified. Culture broth was used for the isolation of mesophilic bacteria, blood broth for hemolytic bacteria, C-EC broth for coliform bacteria and Sabourand maltose broth for the isolation of fungi. The duration of sampling was 10 seconds and the volume of sampled air was 10 liters, as the largest number of microorganisms in the air can be expected in the fattening phase (Donh am et al. 1986). Samples were taken at 9 places (from the front, middle and rear on the left, middle and right side of the fattening object) in the level of animal biozone, i.e. $50 \mathrm{~cm}$ from the flooring.

\section{Microbiological examination}

After the air sampling, petri dishes with bacterial and fungal culture media were incubated at $37^{\circ} \mathrm{C}$ during 24 $\mathrm{h}$ (culture and blood medium), $48 \mathrm{~h}$ (C-EC medium) and 5 days at $22{ }^{\circ} \mathrm{C}$ (Sabouraud maltose medium). Colonies were counted with electronic colony counter (Selecta, Spain). Counting was performed according to the standard procedure on petri dishes with colony numbers between 30 and 300 . The number of colonies obtained was corrected according to correction tables, which are an integral part of the manufacturer's instructions for use. Numbers of bacteria and fungi obtained from the air were expressed as numbers of colonies per $\mathrm{m}^{3}\left(\mathrm{CFU} / \mathrm{m}^{3}\right)$ of air. Isolated bacteria and fungi were identified microscopically and with API tests (Bio Mérieux, France) . The API tests contained a ribbon with corresponding dehydrated culture media and served for reading biochemical reactions and for identifying microorganisms.

Measurement of microclimatic parameters

Control of primary microclimatic conditions: air temperature, relative humidity, airflow speed and ammonia concentration was performed by portable digital instruments (Testo and Dräger, Germany) after each air sampling. 
Statistical analysis

Statistical evaluation of the total bacterial numbers was done with STATISTICA software for Windows, version 6.0 (Stat Soft, Inc.) by means of $t$-test of dependent variables, whereas microclimatic conditions were calculated as mean values.

\section{Results}

In Table 1 the mean values for mesophilic, haemolytic, coliform bacteria and fungi numbers are presented as determined at the facilities with different numbers of animals housed. According to the acquired data the reduction of animal numbers in the object significantly influenced the reduction of all microorganism species except for coliform bacteria between second (356 animals) and third (312 animals) trial. During the investigation the number of mesophilic bacteria varied between $6.65 \times 10^{4}$ and $4.77 \times 10^{4}$, the number of hemolytic bacteria from $5.8 \times 10^{3}$ to $4.05 \times 10^{3}$, the number of coliform bacteria from $3.28 \times 10^{2}$ to $2.02 \times 10^{2}$, and the number of fungi varied from $7.0 \times 10^{3}$ to $4.8 \times 10^{3}$.

Table 1. Total number of mesophilic, haemolytic, coliform bacteria and fungi calculated from 15 measurements at the fattening facility with different numbers of swine.

\begin{tabular}{|c|c|c|c|c|}
\hline \multicolumn{2}{|c|}{ Airborne microorganisms } & \multicolumn{3}{|c|}{ No. of fattening pigs at facility } \\
\hline & & 440 & 356 & 312 \\
\hline \multirow{4}{*}{ 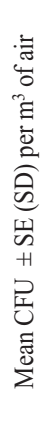 } & Mesophilic bacteria & $\begin{array}{l}6.65 \times 10^{4} \\
\pm 1344.30^{\mathrm{a}} \\
(5206.45)\end{array}$ & $\begin{array}{c}5.34 \times 10^{4} \\
\pm 1042.38^{\mathrm{a}, \mathrm{b}} \\
(4037.13)\end{array}$ & $\begin{array}{c}4.77 \times 10^{4} \\
\pm 1751.86^{\mathrm{a} b \mathrm{~b}} \\
(6784.91)\end{array}$ \\
\hline & Haemolytic bacteria & $\begin{array}{c}5.8 \times 10^{3} \\
\pm 180.70^{\mathrm{a}} \\
(699.84)\end{array}$ & $\begin{array}{c}4.61 \times 10^{3} \\
\pm 164.29 \mathrm{a}, \mathrm{b} \\
(636.30)\end{array}$ & $\begin{array}{c}4.05 \times 10^{3} \\
\pm 133.38^{\mathrm{a}, \mathrm{b}} \\
(516.59)\end{array}$ \\
\hline & Coliform bacteria & $\begin{array}{c}3.28 \times 10^{2} \\
\pm 48.24^{\mathrm{a}} \\
(186.82)\end{array}$ & $\begin{array}{c}2.72 \times 10^{2} \\
\pm 34.81 \\
(134.83)\end{array}$ & $\begin{array}{c}2.02 \times 10^{2} \\
\pm 25.75^{\mathrm{a}} \\
(99.73)\end{array}$ \\
\hline & Fungi & $\begin{array}{c}7.0 \times 10^{3} \\
\pm 173.24^{\mathrm{a}} \\
(670.96)\end{array}$ & $\begin{array}{l}5.4 \times 10^{3} \\
\pm 76.03^{\mathrm{a}, \mathrm{b}} \\
(294.45)\end{array}$ & $\begin{array}{c}4.8 \times 10^{3} \\
\pm 101.61^{\mathrm{a}, \mathrm{b}} \\
393.52)\end{array}$ \\
\hline
\end{tabular}

$\mathrm{a}, \mathrm{b}=$ mean values in the same line, assigned with same letters differ significantly at $p<0.05$

Bacterial species found during all three trials were almost identical, with the exception of finding Pasteurella haemolytica and Pasteurella pneumoniae in trial II, and Proteus vulgaris in trial III. Also, fungal species differ between the trials due to the absence of Penicillium notatum in trial III (Table 2).

Since microclimatic indicators (Table 3 ) indicated that the trials were performed under indentical housing conditions, we may conclude that porcine housing density can reduce the total numbers, but not species varieties, of 9 airborne microorganisms (Fig. 1).

\section{Discussion}

The presence of various microorganisms and their products such as endotoxins, is a significant health problem at swine production facilities. The air in the stable as a transport medium for these microorganisms does not provide conditions for their proliferation, so we could not refer to specific bacterial flora characteristic for any animal facility. It includes well-known stable microorganisms such as gram-positive and gram-negative bacteria and the presence of fungi representing environmental saprophytes (Kiekhaefer et al. 1995). Although the total number of mesophilic bacteria represents a basic assessment of air 
Table 2. Species of airborne microorganisms at the swine fattening facility during the trials.

\begin{tabular}{|c|c|}
\hline Bacteria & Fungi \\
\hline Acinetobacter calco & \\
Aerococcus viridans & \\
Bacillus spp. & \\
E. coli & Aspergillus spp. \\
Lactobacillus lactis lactis & Aspergillus fumigatus \\
Micrococcus spp. & Aspergillus niger \\
Pasteurella haemolytica* & Candida albicans \\
Pasteurella pneumoniae* & Candida crusei \\
Proteus vulgaris** & Mucor spp. \\
Pseudomonas aeruginosa & Penicillium spp. \\
Staphylococcus aureus & Penicillium notatum $* * *$ \\
Staphylococcus cohnii & Trichophyton spp. \\
Staphylococcus epidermidis Staphylococcus spp. & Trichosporon spp. \\
Staphylococcus huminis & \\
Staphylococcus intermedius, Staphylococcus simulans & \\
Staphylococcus saprofiticus, Staphylococcus sciuri & \\
Staphylococcus xylosus & \\
\hline
\end{tabular}

* Bacterial species identified during trial II (356 animals in the object)

** Bacterial species identified during trial III (312 animals in the object)

*** Fungal species identified during trials II and III.

Table 3. Average values of microclimatic variables obtained during each trial at the swine fattening facility.

\begin{tabular}{|c|c|c|c|c|}
\hline $\begin{array}{c}\text { Trial No. } \\
\text { No. of pigs) }\end{array}$ & $\begin{array}{c}\text { Air temperature } \\
\left({ }^{\circ} \mathrm{C}\right)\end{array}$ & $\begin{array}{c}\text { Relative humidity } \\
(\%)\end{array}$ & Air flow speed (m/s) & $\begin{array}{c}\text { Ammonia } \\
\text { concentration }(\mathrm{ppm})\end{array}$ \\
\hline I (440) & 17.5 & 77 & 0.2 & 11 \\
\hline II (356) & 18.5 & 67 & 0.2 & 8 \\
\hline III (312) & 23 & 72 & 0.4 & 7 \\
\hline
\end{tabular}

hygiene quality, we selected a wider range of selective growth media in order to obtain a better insight into microbiological status of air at the swine fattening facility. Referring to different survival capabilities of microorganisms, the method of cultivation on different growth media presents one of the most suitable approaches used in bioaerosole research because it enables to determine the number as well as the species of microorganism ( $\mathrm{Ch}$ ang et al. 2001). To determine microorganism numbers in the air, a device is necessary that enables microorganism sampling. For this purpose, the most widely used method today includes airflow bursts directly on the growth medium, i.e. the impact. The Andersen sampler has been in practical use for a long time (Andersen 1958; Brachmann et al. 1964; Curtis et al. 1978; Gilles pie et al. 1981). In this study, a more sophisticated version of this sampler (SAS 100 ${ }^{\mathrm{TM}}$ ) (Buttner and Stetzenbach 1993) was used. Much data has already been published on airborne microorganism numbers at swine fattening facilities, following the use of various devices for air sampling. However, each device has limited technical capabilities, such as sampling only air particles of a particular size. Consequently, it is not possible to perform a relevant comparison of the data obtained in our study with those of the others. However, as there is no accurate standardized method that is scientifically recommended for air sampling, and no standard values of airborne microorganism numbers in the technological phases of the swine production, the data obtained in various investigations may be analyzed and compared, considering them as original and trustworthy, although preliminary information (Homes et al. 1999) that can 

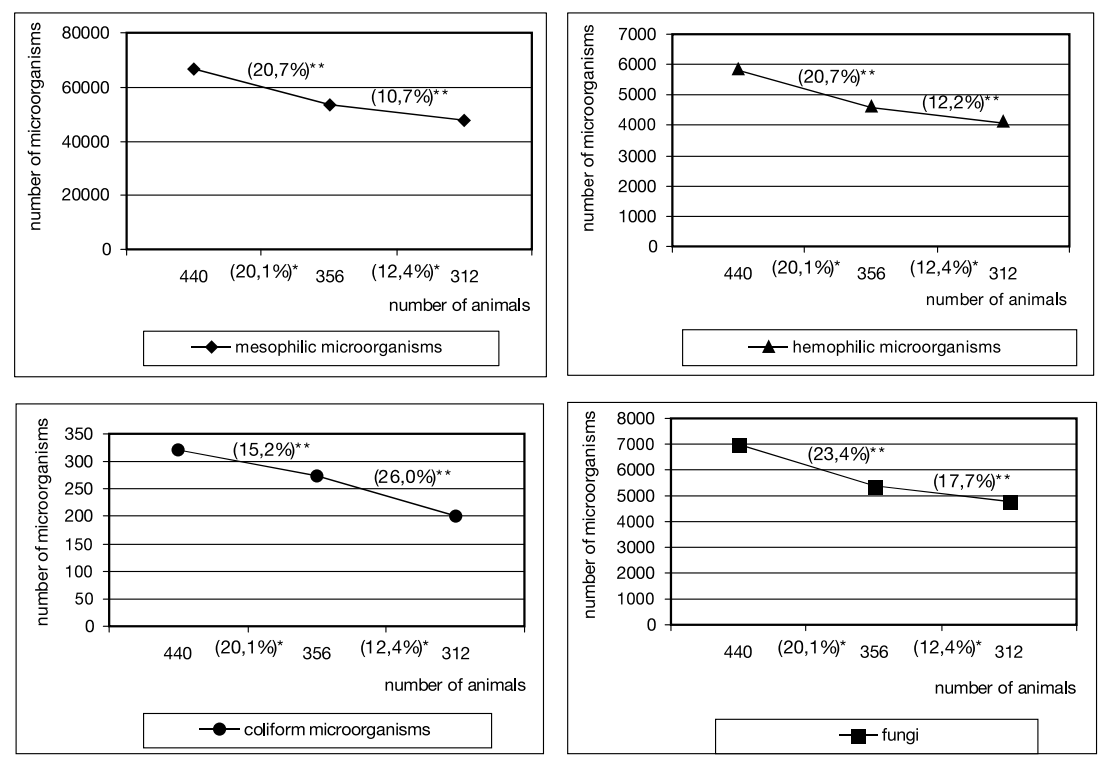

\footnotetext{
* percent reduction of swine numbers between trials I and II and trials II and III.

** percent reduction of tested microorganisms between trials I and II and trials II and III.
}

Fig. 1. Percent reduction of airborne microorganism numbers in relation to the number of housed fattening swine.

serve to establish reference values. Highly variable data on the total number of bacteria in the fattening unit, ranging from $10^{4}$ to $10^{6} \mathrm{CFU} / \mathrm{m}^{3}$ (Att w o od et al. 1987; D on ham 1991; Chang et al. 2001), have been published. The results of our study, regardless of animal numbers at the facility, are comparable to these values, and are even lower (not exceeding valnes of $10^{4} \mathrm{CFU}$ per $\mathrm{m}^{3}$ ) than those described by the former authors (Table 1). Based on these findings we may conclude that the environment was beneficial for their health, as observed earlier (Fišer 1970). Namely, during the entire study there was only one death at the end of the third trial, caused by heart failure. Besides that, no bacterial or fungal infections were recorded that would require treatment.

The concentration of microorganisms in the air is of great importance as much as the presence of particular species considering their potential pathogenic effect on the health status of swine (Köfer et al. 1993). Most significant microorganisms recorded during the three trials were gram-positive bacteria followed by gram-negative bacteria and fungi (Table 2). Gram-positive bacteria are generally most prevalent in the stable air, which may be explained by their high resistance in the environment (Hartung 1998). On the other hand, the proportion of gram-negative bacteria (coliform and other enterobacteriae) is always lower, which can be attributed to their weak survival capability in the air (Zucker and Müller 2002). As a potential endotoxin carrier, gram-negative bacteria present a very important microorganism group, which may negatively affect animal health. Thus, it is assumed that their numbers in the air should not exceed $10^{3} \mathrm{CFU} / \mathrm{m}^{3}$ ( Clark et al. 1983) which is in agreement with our findings (Table 1).

Fungi are a part of the normal microflora in animal housing, but some species, such as Penicillium sp., Aspergillus sp. and Fusarium sp., may be the cause of allergies, asthma and various mycotoxicosis (Kiekhaefer et al. 1995). Fungal numbers in the air of the swine fattening facility differ between $10^{3}$ and $10^{5} \mathrm{CFU} / \mathrm{m}^{3}$ (Don ham 1991; Chang et al. 2001), 
which is comparable to our results for these microorganisms (Table 1). Bacteria and fungi identified in our trials were also recorded in other studies (Cormier et al. 1990; Kiekhaefer et al. 1995).

Microorganism concentration in the air can be influenced by the season, and their numbers are predominantly lower during the summer period (Müller 2000). These authors consider high temperature, which requires higher airflow values during the summer months, as a main reason for lower microorganism levels. Higher airflow values may cause greater particle dissipation in the air, which leads to greater emissions of these particles in the environment. However, other authors have determined greater microorganism numbers in the warmer part of the year (Kiekhaefer et al. 1995), which causes difficulties in the interpretation of our results regarding the season (Table 3). Moreover, the ventilation system at the facility kept the microclimatic conditions without significant variations during our trials. Also, during the warm season of the year (spring summer) the animal number was the lowest (312 animals) in all trials. Thus, the obtained values of mesophilic, haemolytic, coliform bacteria and fungi should be considered more through their population density at the facility during the individual trials. Namely, the data obtained suggest that lowering the animal numbers significantly reduces all microorganism species and population in the air. Comparing these percentages, it is clear that the relation between lower animal numbers and lower microorganism numbers is proportional, except for coliform bacteria (Fig. 1), which could be explained by their predominantly lower levels in the stable air. Therefore, we can conclude that microorganism levels in the air are influenced by the number of animals per unit of housing space, and by ventilation system that affects primary microclimatic conditions at the facility, similarly as it was observed by Seedorf et al. (1998). Thus, with the reduction of swine numbers at the fattening facility with identical housing conditions and adequate microclimate, proportional reduction of total microorganism numbers can be expected. These findings could be used in planning the capacity in the context of animal welfare.

\section{Vliv hustoty obsádky prasat ve výkrmu na spektrum a počet mikroorganismů v stájovém vzduchu}

Mikrobiologická skladba vzduchu může jako faktor vnějších podmínek výrazně ovlivňovat produkci, zdraví a welfare v chovu prasat. Cílem pokusů bylo pomocí monitoringu primárních mikroklimatických podmínek zjistit možný vztah mezi počtem prasat na jednotku ustájení ve výkrmu s rozmanitostí a počtem vzdušných mikroorganismů. Studie byla provedena ve výkrmně o ploše $450 \mathrm{~m}^{2}$ (vybavené 44 kotci o kapacitě 10 zvířat) s nízkotlakou ventilací a sestávala se ze tří různých pokusů. První pokus byl proveden v období podzim-zima s 440 zvířaty $\left(0,7 \mathrm{~m}^{2}\right.$ plochy kotce na jedno prase ve výkrmu). Druhý pokus byl proveden v období zima-jaro s 356 zvířaty $\left(0,8 \mathrm{~m}^{2}\right.$ plochy kotce na jedno prase ve výkr$\mathrm{mu})$. Třetí pokus byl proveden v období jaro-léto s 312 zvířaty $\left(1,0 \mathrm{~m}^{2}\right.$ plochy kotce na jedno prase ve výkrmu). V nepřetržitých týdenních intervalech byly ve všech pokusech odebírány vzorky vzduchu k izolaci plísní a mezofilních, haemolytických a koliformních bakterií a sledovány mikroklimatické podmínky.

Podle dat získaných ze všech pokusů nepřesáhl počet bakterií a plísní 104 a 103 CFU na m3. Nejpočetnější byly gram-pozitivní bakterie, následovaly gram-negativní bkterie a plísně. Celkový počet vzdušných mikroorganismů koreloval signifikantně s hustotou ustájení prasat ve výkrmu $(p<0,05)$. Výsledky lze využít pro určování takové hustoty ustájení prasat ve výkrmu, která nebude v důsledku mikrobiologické kvality vzduchu negativně ovlivňovat zdraví a welfare zvířat a přispěje k zavedení optimálních chovatelských podmínek do velkochovů hospodářských zvířat. 


\section{References}

ANDERSEN AA 1958: New sampler for the collection, sizing and enumeration of viable airborne particles. J Bacteriol 76: 471-484

ATTWOOD PR, BROUWER P, RUIGEWAARD P, VERSLOOT R, DE WIT D, HEEDERIK JS, BOLEIJ M 1987: A study of the relationship between airborne contaminants and environmental factors in Dutch swine confinement buildings. Amer Ind Hyg Assn J 48: 745-751

BRACHMAN PS, EHRLICH R, EICHENWALD HF, CABELI VJ, KETHLEY TW, MADIN

SH, MALTMAN JR, MIDDLEBROOK G, MORTON JD, SILVER IH, WOLFE EH 1964: Standard sampler for assay of airborne microorganisms. Science 144: 1295

BUTTNER MP, STETZENBACH LD 1993: Monitoring airborne fungal spores in an experimental indoor environment to evaluate sampling methods and the effects of human activity on air sampling. Appl Environ Microbiol 59: 219-226

CHANG CW, CHUNG H, HUANG CF, SU HJJ 2001: Exposure of workers to airborne microorganisms in open air swine houses. Appl Environ Microbiol 67 : 155-161

CLARK S, RYLANDER R, LARSSON L 1983: Airborne bacteria, endotoxin and fungi in dust in poultry and swine confinement buildings. Amer Ind Hyg Assn J 44: 537-541

CORMIER Y, TREMBLAY G, MERIAUX A, BROCHU G, LAVOIE J 1990: Airborne microbial contents in two types of swine confinement buildings in Quebec. Amer Ind Hyg Assn J 51: 304-309

CURTIS SE, BALSBAUGH RK, DRUMMOND JG 1978: Comparison of Andersen eight-stage and two-stage viable air samplers. Appl Environ Microbiol 35: 208- 209

DONHAM KJ, SCALLON LJ, POPENDORF W, TREUHAFT MW, ROBERTS R 1986: Characterization of dusts collected from swine confinement buildings. Amer Ind Hyg Assn J 47: 404-410

DONHAM KJ 1991: Association of environmental air contaminants with disease and productivity. Amer J Vet Res 52. 1723-1730

DUCHAINE C, GRIMARD Y, CORMIER Y 2000: Influence of building maintenance, environmental factors and season on airborne contaminants of swine confinement building. Amer Ind. Hyg Assn J 61: 56-63

FIŠER A 1970: Microbiological picture of air in large scale farrowing house and prefeeding piggery. Acta Vet Brno 39: $89-100$

GILLESPIE VL, CLARK CS, BJORNSON HS, SAMUELS SJ, HOLLAND JW 1981: Acomparison of two- stage and six-stage Andersen impactors for viable aerosols. Amer Ind Hyg Assn J 42: 858-864

HADINA S, VUČEMILO M, PAVIČIĆ Ž, TOFANT A, MATKOVIĆ K 2003: Effect of microclimate on air quality in intensive pig production. Stočar 57: 91-99

HARTUNG J 1998: Freisetzung partikelförmiger Stoffe aus einem Schweinstall mit zentraler Abluftführung in die Stallumgebang. Dtsch Tierarztl Wochenschr 105: 244-245

HOMES MJ, HEBER AJ, WU CC, CLARK LK, GRANT RH, ZIMMERMAN NJ, HILL MA, STROBEL BR, PEUGH MW, JONES DD 1999: Viability of bioaerosols produced from a swine facility. http://www.anr.ces.purdue.edu

KIEKHAEFER MS, DONHAM KJ, WHITTEN P, THORNE PS 1995: Cross seasonal studies of airborne microbial populations and environment in swine buildings: implications for worker and animal health. Ann Agri Environ Med 2: 37-44

KLUCZEK S, KLUCZEK JP 2000: Bacterial microflora in the piggery. In: Proceedings of the $10^{\text {th }}$ International Congress in Animal Hygiene, Academic Press Inc, Maastricht, pp. 642-645

KÖFER F, AWAD-MASALMEH M, THIEMANN G (1993): Der Einfluß von Haltung, Management und Stallklima auf die Lungenveränderungen bei Schweinen. Dtsch Tierarztl Wochenschr 100: 319-322

MÜLLER WP 2000: Emission und Imission von Staub und Mikroorganismen aus Stallanlagen. In: Umwelt und tiergerechte Haltung von Nutz-, Heim- und Begleittieren (Ed. by WJ Methling). Unshelm - Hrsg, Parey Buchverlag - Berlin, pp. 27-33

SEEDORF J, HARTUNG J, SCHRÖDER M, LINKERT KH, PEDERSEN S, TAKAI H, JOHNSEN JO, METZ JHM, GROOT KOERKAMP PWG, UENK GH, PHILLIPS VR, HOLDEN MR, SNEATH RW, SHORT JL, WHITE RP, WATHES CM 1998: A survey of ventilation rates in livestock buildings in North Europe. J Agr Engin Res 70: $39-47$

WATHES CM 1994: Air and surface hygiene. In: Livestock housing (Ed. CM Wathes). CAB International Press, Wallingford, pp.123-148.

ZUCKER BA, TROJAN S, MÜLLER W 2000: Airborne gram-negative bacteria flora in animal houses. J Vet Med 47: 37-46

ZUCKER BA, MÜLLER W 2000: Untersuchungen zum Luftkeimhaushalt in Tierställen. 3. Mitteilung: Beziehungen zwischen einatembarem Endotoxin, einatembarem Staub und luftgetragenen Bakterien in einer Legehennenbatterie. Luftgetragene gramnegative Bakterien und luftgetragenes Endotoxin in Schweinställen. Berl Mun Tierarztl Wochenschr 113: 279-283

ZUCKER BA, MÜLLER W 2000: Species composition and sources of airborne gram-negative bacteria in animal houses. In: Proceedings of the $10^{\text {th }}$ International Congress in Animal Hygiene. Academic Press Inc, Maastricht, pp. 393-397 
ZUCKER BA, MÜLLER W 2002: Untersuchungen zum Luftkeimhaushalt in Tierställen. 4. Mitteilung: Luftgetragene gramnegative Bakterien und luftgetragenes Endotoxin in Schweinställen. Berl Mun Tierarztl Wochenschr 115: 30-36 